\title{
Novel mutation in TENM3 gene in an Iranian patient with Colobomatous Microphthalmia
}

\author{
Sepideh Gholami Yarahmadi ${ }^{1}$, fatemeh sarlaki ${ }^{2}$, and Saeid Morovvai ${ }^{1}$ \\ ${ }^{1}$ Islamic Azad University Tehran Medical Sciences \\ ${ }^{2}$ Shahid Beheshti University of Medical Sciences
}

January 24, 2022

\begin{abstract}
Anophthalmia AO and microphthalmia MO have both heritable and environmental causes. The proband described in this study was a 32-year-old symptomatic The detected homozygous canonical splice site variant in the TENM3 gene has not been reported up to now for its pathogenicity and can be considered as a novel mutation.
\end{abstract}

Novel mutation in TENM3 gene in an Iranian patient with Colobomatous Microphthalmia Sepideh Gholami Yarahmadi ${ }^{b}$, Fatemeh Sarlaki ${ }^{a}$, Saeid Morovvati ${ }^{b}$

Shahid Beheshti University of Medical Scinences, Tehran, Iran

School of Advanced Sciences and Technology, Islamic Azad University-Tehran Medical Sciences, Tehran, Iran

\begin{abstract}
:
Microphthalmia, anophthalmia, and coloboma (MAC) display a range of MAC ocular malformations. Anophthalmia $(\mathrm{AO})$, and microphthalmia $(\mathrm{MO})$, are the worst congenital deformities of the eye in terms of severity, with a prevalence of around 1 in 30,000 and 1 in 7,000 births, in turn. AO refers to the complete absence of the optic tissue structure or the structures of visible ocular with remnants that can be detected histologically. MO is defined as a decrease in the ocular globe size. Based on epidemiological studies, AO and MO have both heritable and environmental causes, with genetic defects being the majority of common causes. The proband described in this study was a 32-year-old symptomatic male with mild intellectual disability, bilateral decrease in the ocular globe size, and coloboma living in Sari city of Iran diagnosed as having nonsyndromic bilateral colobomatous microphthalmia based on his clinical and paraclinical features. His parents were first cousins, and there was a positive family history in his pedigree. Human whole-exome enrichment was performed, and 35 genes related to the disease were analyzed. Sanger validation of the TENM3 gene endorsed the fact that the proband had a homozygous c.5069-1G $>\mathrm{C}$ variation. The detected homozygous canonical splice site variant in the TENM3 gene has not been reported up to now for its pathogenicity and can be considered as a novel mutation. Founded on the ACMG guideline, this variant can be categorized as pathogenic. The present finding can be used for genetic diagnosis and detection of carriers in the family and other patients with similar disease manifestations.
\end{abstract}

\section{KEYWORDS}

Microphthalmia, TENM3, Gene, Novel, Mutation, Coloboma

Introduction: 
Microphthalmia, anophthalmia, and coloboma (MAC) display a range of MAC ocular malformations [1]. The conditions of MAC are mostly related to further ocular and non-ocular anomalies, demonstrating the gene association accountable for several processes of development. It is reported that almost $33 \%$ of reported cases affected with MAC are syndromic and have abnormalities such as the craniofacial, renal, genital, cardiac, brain, skeletal, etc. [2].

Anophthalmia (AO), MIM 206900, and microphthalmia (MO), MIM 309700, are the worst congenital deformities of the eye in terms of severity, with a prevalence of around 1 in 30,000 and 1 in 7,000 births, in turn [3]-[5]. AO refers to the complete absence of the optic tissue structure [6], [7], or the structures of visible ocular with remnants that can be detected histologically [8]. MO is defined as a decrease in the ocular globe size (total axial length of $<19 \mathrm{~mm}$ in 1 -year-old children and $<21 \mathrm{~mm}$ in adults) [6], [9], [10].

These defects can be syndromic or isolated [11], [12], and may occur unilateral or bilateral [6] with abnormalities occurring in the vitreous (persistent fetal vasculature), lens (congenital cataract), anterior segment (sclerocornea or Peters anomaly, microcornea, iris coloboma), and/or posterior segment (optic coloboma) [13]-[17].

MO can be categorized into simple MO and complex MO based on the presence of other ocular malformations or systemic diseases. The simple MO is defined as an eye reduced in size but with normal shape, except for the short axial length. [10] In comparison, the complex MO occurs along with other eye deformities, such as chorioretinal coloboma, iris coloboma, retinal coloboma, and persistent fetal vasculature [12], [14], [18], [19].

Based on epidemiological studies, AO and MO have both heritable and environmental causes, with genetic defects being the majority of common causes [12], [14], [19], [20]. Beyond 30 genes are associated with the non-syndromic AO and MO pathogenesis, the main causative of which are RAX (MIM 601881), OTX2 (MIM 600037), PAX6 (MIM 607108), FOXE3 (MIM 6011094) [14], [20], and SOX2 (MIM 184429) [21].

Based on the reports, several chromosomal abnormalities such as trisomy 13, mosaic trisomy 9, del7p15.1p21.1, del14q22.1q23.2, delXp22.3, del16p11.2, del16q11.2q12.2, dup10q24.31, and dup15q11.2q13.1, and also some point mutations are involved in MO. The rearrangement of chromosomes has been identified mainly related to syndromic MO, while single-nucleotide variants could be detected in both non-syndromic and syndromic forms [20], [22]. As several genes are involved in most cases of chromosomal rearrangements, the resulting disorder is usually syndromic, while disorders caused by point mutations can be syndromic or non-syndromic, depending on the type of mutations and involved genes. Due to the incidence of de novo mutations, incomplete penetrance, mosaicism, and sporadic occurrence, genetic counseling is not easy[3].

In this study, we investigated the genetic basis of microphthalmia in an affected Iranian proband and reviewed the reported spectrum of the TENM3 gene mutations involved in this disorder.

\section{Material and methods:}

A 32-year-old symptomatic male with mild intellectual disability, bilateral decrease in the ocular globe size, and coloboma living in Sari city of Iran diagnosed as having bilateral colobomatous microphthalmia based on his clinical and paraclinical features. His parents were first cousins, and there was a positive family history in his pedigree. First cousin of our patient's father (case III-3) is also affected by Mo and Coloboma, without intellectual disability (The patient did not consent to the genetic test). After genetic counseling and drawing the familial pedigree (Figure 1), the proband gave his informed consent before the inclusion in this experiment. DNA extraction was done from whole blood using standard extraction methods. Human wholeexome enrichment was performed using Twist Human Core Exome Kit, and the library was sequenced on Illumina platform with a raw coverage of $260 \mathrm{X}$ and mean on-target coverage of 105X, performed by CeGaT $\mathrm{GmbH}$, Germany. Only data related to the 35 genes of interest were extracted for further analysis (Name of these genes and their inheretence patterns are mentioned in Table 1 based on OMIM databases). Our panel of 35 genes is based on the genes listed in the OMIM Database for this disease, including genes that cause the isolated disease and genes that cause the syndromic type. For each disease, a panel of genes is introduced in the OMIM database, and in the study of that disease, all those genes are examined, whether 
they are the cause of syndromic or cause of isolated type. On the other hand, because it was possible that the patient's intellectual disability was not associated with microphthalmia, we examined both isolated and syndromic-type causative genes. Nearly all exons and flanking 10bp in these genes were detected and analyzed. The NGS method's analytical sensitivity and specificity used in this assay to detect single point mutations and small indels (within 20bp) are assumed to be $>95 \%$.

\section{Table 1}

\begin{tabular}{|c|c|c|c|c|c|c|c|}
\hline Number & Official Symbol & Inheritance & MIM number & Number & Official Symbol & Inheritance & MIM n \\
\hline 1 & $A B C B 6$ & $\mathrm{AD}$ & 605452 & 13 & $H C C S$ & XLD & 300056 \\
\hline 2 & ALDH1A3 & $\mathrm{AR}$ & 600463 & 14 & $H E S X 1$ & $\mathrm{AD}, \mathrm{AR}$ & 601802 \\
\hline 3 & $B C O R$ & XLD & 300485 & 15 & $I K B K G$ & $\backslash$ soutMO & $\backslash$ soutMC \\
\hline 4 & BEST1 & s soutMo & \soutNo MO & 16 & $M F R P$ & AR & 606227 \\
\hline 5 & B3GALNT2 & AR & 610194 & 17 & $M K S 1$ & \soutMO & $\backslash$ soutMC \\
\hline 6 & $B M P 4$ & $\mathrm{AD}$ & 112262 & 18 & $N D P$ & ssoutMO & IsoutMC \\
\hline 7 & CHD' & $\backslash$ soutMO & \soutMO & 19 & OTX2 & $\mathrm{AD}$ & 600037 \\
\hline 8 & $C O X 7 B$ & XLD & 300885 & 20 & $P A X \mathscr{2}$ & $\mathrm{AD}$ & 167409 \\
\hline 9 & $E R C C 6$ & $\mathrm{AR}$ & 609413 & 21 & $P A X 6$ & $\mathrm{AD}$ & 607108 \\
\hline 10 & $E R C C 8$ & $\backslash$ soutMO & $\backslash$ soutMO & 22 & РІTXЗ & $\mathrm{AD}, \mathrm{AR}$ & 602669 \\
\hline 12 & GDF3 & $\mathrm{AD}$ & 606522 & 23 & POMT1 & $\mathrm{AR}$ & 607423 \\
\hline 11 & GDF6 & $\mathrm{AD}$ & 601147 & 24 & PRSS56 & $\mathrm{AR}$ & 613858 \\
\hline
\end{tabular}

Table 1: Checked genes related to microphthalmia (AD: Autosomal Dominant, AR: Autosomal Recessive, XLD: X-linked Dominant)

\section{Result:}

The proband described in this study had clinical manifestations such as mild intellectual disability, bilateral decrease in the ocular globe size, and coloboma, which conform to the diagnosis of non-syndromic bilateral colobomatous microphthalmia. Both parent's detailed ocular examination was normal. The patient's parents were normal based on eye examinations performed by a specialist physician.

Sanger validation of the TENM3 gene endorsed the fact that the proband had a homozygous c.5069-1G $>$ C variation (Figure 2). The detected homozygous canonical splice site variant in the TENM3 gene has not been reported up to now for its pathogenicity. However, based on various silico computational analyses mentioned in the Varsome database for pathogenicity scores such as BayesDel addAF, BayesDel noAF, DANN, EIGEN, EIGEN PC, FATHMM-MKL, and Mutation Taster, the variant has a deleterious effect on the gene or gene product(s). Founded on the American College of Medical Genetics and Genomics (ACMG) guideline, this variant can be categorized as pathogenic (PVS1: Very Strong, PM2: Moderate, PP3: Supporting).

\section{Discussion:}

Congenital malformations of the eye are one of the main reasons for blindness and ocular morbidity in childhood. Considering almost 4000 genetic disorders and syndromes, which have an effect on humans, at least $33 \%$ affects the eye [23].

The TENM3 gene encodes the Teneurin transmembrane protein 3 in humans, which has been investigated for its role in the development of the eye, adhesion of homophilic cells, and axon guidance [24], [25]. This protein consists of 2699 amino acids (NP_001073946.1). The family of Teneurin includes 4 distinct types of transmembrane dimeric proteins (TENM1-4) [26].

It has been shown that the TENM3 gene expresses in the nervous system and a restricted set of mesodermderived tissues. It has been suggested that the TENM3 gene plays a vertebrate orthologue conserved role in ocular development as it was detected to be mainly enriched in the optic stalk. [24] Due to the strong brain 
teneurins expression in neuronal subpopulations and the positional mapping, there could be a connection to intellectual disability, especially during development [27].

To the best of our knowledge, 7 mutations have been reported in the TENM3 gene in 6 unrelated families, 6 of which are ascribed eye anomalies. Our report would be the $7^{\text {th }} \mathrm{MO}$ and coloboma causative mutation in this gene [2], [26], [28]-[31]. You can see the information of these seven mutations in table 2.

The first mutation of the TENM3 gene was reported in two siblings of a consanguineous family. These brothers were both suffering from isolated bilateral microphthalmia, microcornea, and retinal and iris coloboma. The homozygous c.2083dup variant was detected in them while their parents were unaffected carriers [28].

A homozygous splice mutation (c.2968-2A > T) in the TENM3 gene was detected in a son of 9 from a consanguineous family. The proband was affected by bilateral colobomatous microphthalmia and developmental delay [2].

Two novel compound heterozygous variations (c.4046C $>\mathrm{G}$ and c.7687C $>\mathrm{T}$ ) in the TENM3 gene was found in a boy of 6 , with eye anomalies and intellectual disability [29].

Another novel mutation (c.1857T $>$ A) in the homozygous state in the TENM3 gene has been reported in two sisters from nonconsanguineous parents. These siblings did not have microphthalmia, but they had ptosis, developmental delay, and iris coloboma [26].

Feldman et al. found a homozygous c.7994A $>$ C variant in theTENM3 gene in 3 affected patients of a 4 generation family who were suffering from developmental dislocation of the hip [30].

In addition, Islam et al. identified c. $1558 \mathrm{C}>\mathrm{T}$ (a pathogenic homozygous variant) in the TENM 3 gene in a patient who was suffering from cataracts, bilateral iris, and chorioretinal colobomas microphthalmia [31].

Therefore, it seems that the TENM3 gene is vital in the eye development process, and pathogenic variations of this gene could bring about MAC ocular malformations spectrum and intellectual disability. The detected mutation in our case, c.5069-1G >C , has not been reported before and can be considered as a novel mutation. The present finding can be used for genetic diagnosis and detection of carriers in the family and other patients with similar disease manifestations.

\section{Table 2}

\begin{tabular}{|c|c|c|c|c|c|c|c|c|}
\hline $\begin{array}{l}\text { Clinical } \\
\text { characteristics }\end{array}$ & {$[28]$} & [28] & {$[2]$} & [29] & {$[26]$} & {$[26]$} & {$[31]$} & $\begin{array}{l}\text { This } \\
\text { study }\end{array}$ \\
\hline Mutation & $\begin{array}{l}\text { Homozygous } \\
\text { c.2083dup; } \\
\text { p. } \\
\text { Thr695Asnfs* }\end{array}$ & $\begin{array}{l}\text { Homozygous } \\
\text { c.2083dup; } \\
\text { p. } \\
\text { 5Thr695Asnfs* }\end{array}$ & $\begin{array}{l}\text { Homozygous } \\
\text { c. } 2968- \\
2 \mathrm{~A}>\mathrm{T} ; \\
5 \mathrm{p} . \text { Val990Cysf }\end{array}$ & $\begin{array}{l}\text { Compound } \\
\text { heterozy- } \\
\text { gous } \\
\text {; } 13687 \mathrm{C}>\mathrm{T} \text {; } \\
\text { p. } \\
\text { Arg2563Trp } \\
\text { and } \\
\text { c. } 4046 \mathrm{C}>\mathrm{G} \text {; } \\
\text { p. } \\
\text { Ala1349Gly }\end{array}$ & $\begin{array}{l}\text { Homozygous } \\
\text { c. } 1857 \mathrm{~T}>\mathrm{A} \text {; } \\
\text { p. Cys619* }\end{array}$ & $\begin{array}{l}\text { Homozygous } \\
\text { c. } 1857 \mathrm{~T}>\mathrm{A} \text {; } \\
\text { p. Cys } 619^{*}\end{array}$ & $\begin{array}{l}\text { Homozygous } \\
\text { c. } 1558 \mathrm{C}>\mathrm{T} ; \\
\text { p. }\left(\operatorname{Arg} 520^{*}\right)\end{array}$ & $\begin{array}{l}\text { Homoz } \\
\text { c. } 5069- \\
1 \mathrm{G}>\mathrm{C} \\
\text { p. } 1690 \mathrm{I}\end{array}$ \\
\hline $\begin{array}{l}\text { Type of } \\
\text { mutation }\end{array}$ & Frameshift & Frameshift & Splice & Missense & Nonsense & Nonsense & Nonsense & frames \\
\hline $\begin{array}{l}\text { Exon/intron } \\
\text { contain- } \\
\text { ing } \\
\text { mutation }\end{array}$ & Exon 12 & Exon 12 & $\begin{array}{l}\text { Intron } \\
16\end{array}$ & $\begin{array}{l}\text { Exon } 22 \\
\text { and } \\
\text { exon } 28\end{array}$ & E11 & E11 & E9 & $\begin{array}{l}\text { Intron } \\
23\end{array}$ \\
\hline Consanguinity & Yes & Yes & Yes rep04 & $\begin{array}{l}\text { No } \\
\text { INTELL1 }\end{array}$ & NO 16 & NO 16 & Yes 017 & Yes \\
\hline
\end{tabular}




\begin{tabular}{|c|c|c|c|c|c|c|c|c|}
\hline Origin & $\begin{array}{l}\text { Saudi } \\
\text { Arabia }\end{array}$ & $\begin{array}{l}\text { Saudi } \\
\text { Arabia }\end{array}$ & France & India & India & India & Pakistan & Iran \\
\hline Gender & Male & Female & Male & Male & Female & Female & $\begin{array}{l}\text { Not } \\
\text { given }\end{array}$ & Male \\
\hline Age & 11 & 9 & 9 & 6 & $\begin{array}{l}5 \text { years } \\
\text { and } \\
6 \text { months }\end{array}$ & $\begin{array}{l}\text { 3years } \\
\text { and } \\
\text { 4months }\end{array}$ & $\begin{array}{l}\text { Not } \\
\text { given }\end{array}$ & 32 \\
\hline $\begin{array}{l}\text { Motor } \\
\text { development }\end{array}$ & Normal & Normal & Delayed & Delayed & Delayed & Delayed & $\begin{array}{l}\text { Not } \\
\text { given }\end{array}$ & Normal \\
\hline Cognition & Normal & Normal & Delayed & Delayed & Delayed & Normal & $\begin{array}{l}\text { Not } \\
\text { given }\end{array}$ & Delayec \\
\hline Ptosis & No & No & No & No & $\begin{array}{l}\text { Unilateral } \\
\text { (left) }\end{array}$ & $\begin{array}{l}\text { Bilateral } \\
\text { partial } \\
\text { ptosis }\end{array}$ & $\begin{array}{l}\text { Not } \\
\text { given }\end{array}$ & yes \\
\hline \multicolumn{2}{|c|}{ MicrophthalmiXes } & Yes & Yes & $\begin{array}{l}\text { Yes } \\
\text { (right } \\
\text { eye) }\end{array}$ & No & No & Yes & Yes \\
\hline $\begin{array}{l}\text { Micro } \\
\text { cornea }\end{array}$ & Yes & Yes & Yes & $\begin{array}{l}\text { Bilateral } \\
\text { sclerocornea }\end{array}$ & Yes & Yes & $\begin{array}{l}\text { Not } \\
\text { given }\end{array}$ & $?$ \\
\hline $\begin{array}{l}\text { Corneal } \\
\text { shape }\end{array}$ & Oval & $\begin{array}{l}\text { Not } \\
\text { given }\end{array}$ & $\begin{array}{l}\text { Not } \\
\text { given }\end{array}$ & $\begin{array}{l}\text { Not } \\
\text { given }\end{array}$ & $\begin{array}{l}\text { Vertically } \\
\text { oval }\end{array}$ & $\begin{array}{l}\text { Vertically } \\
\text { oval }\end{array}$ & $\begin{array}{l}\text { Not } \\
\text { given }\end{array}$ & $?$ \\
\hline $\begin{array}{l}\text { Iris } \\
\text { coloboma }\end{array}$ & Inferior & Inferior & Inferior & $\begin{array}{l}\text { Not } \\
\text { given }\end{array}$ & Inferonasal & Inferonasal & $\begin{array}{l}\text { bilateral } \\
\text { iris and } \\
\text { chori- } \\
\text { oretinal } \\
\text { colobomas }\end{array}$ & $?$ \\
\hline $\begin{array}{l}\text { Shape } \\
\text { of disc }\end{array}$ & Anomalous & $\begin{array}{l}\text { Not } \\
\text { given }\end{array}$ & $\begin{array}{l}\text { Not } \\
\text { given }\end{array}$ & $\begin{array}{l}\text { Not } \\
\text { given }\end{array}$ & Normal & Normal & $\begin{array}{l}\text { Not } \\
\text { given }\end{array}$ & $?$ \\
\hline $\begin{array}{l}\text { Disc } \\
\text { coloboma }\end{array}$ & Yes & Yes & Yes & $\begin{array}{l}\text { Not } \\
\text { given }\end{array}$ & $\begin{array}{l}\text { Inferonasal } \\
\text { bilateral } \\
\text { involv- } \\
\text { ing } \\
\text { fovea }\end{array}$ & $\begin{array}{l}\text { Inferonasal } \\
\text { bilateral } \\
\text { involv- } \\
\text { ing } \\
\text { fovea }\end{array}$ & $?$ & $?$ \\
\hline $\begin{array}{l}\text { Visual } \\
\text { acuity }\end{array}$ & $\begin{array}{l}20 / 50(\mathrm{R}) \\
\text { Hand } \\
\text { move- } \\
\text { ment } \\
(\mathrm{L})\end{array}$ & $\begin{array}{l}20 / 200(\mathrm{R}) \\
20 / 300(\mathrm{~L})\end{array}$ & $\begin{array}{l}\text { Hand } \\
\text { move- } \\
\text { ment } \\
\text { both } \\
\text { eyes }\end{array}$ & $\begin{array}{l}\text { Not } \\
\text { given }\end{array}$ & $\begin{array}{l}6 / 36 \\
\text { both } \\
\text { eyes }\end{array}$ & $\begin{array}{l}6 / 36 \\
\text { both } \\
\text { eyes }\end{array}$ & $\begin{array}{l}\text { Not } \\
\text { given }\end{array}$ & $?$ \\
\hline
\end{tabular}

Table 2: Characteristics of reported mutations involved in Microphthalmia

Author contributions

Sepideh Gholami Yarahmadi: Genetic Laboratory tests, Data analysis, Sampling, Original Draft

Fatemeh sarlaki : Investigation, -, Resource.

Saeid Morovvati : Conceptualization, Writing - Review \& Editing, Supervision, Formal analysis.

Declaration of competing interest

No conflict of interest is hereby declared by any of the contributing authors.

\section{Acknowledgments}


We appreciate the patient for his collaborative attitude and for accepting to publish the findings. Also, we are grateful to the staff of Rasad Pathobiology and Genetic Laboratory for their intimate collaboration.

\section{Consent for publication}

The patient has provided us with his written consent for publishing this study, and the study was conducted according to the Helsinki Declaration principles.

\section{References:}

[1] L. M. Reis and E. V. Semina, "Conserved genetic pathways associated with microphthalmia, anophthalmia, and coloboma," Birth Defects Research Part C - Embryo Today: Reviews . 2015, doi: $10.1002 /$ bdrc. 21097 .

[2] N. Chassaing et al. , "Confirmation of TENM3 involvement in autosomal recessive colobomatous microphthalmia," Am. J. Med. Genet. Part A, 2016, doi: 10.1002/ajmg.a.37667.

[3] D. Morrison et al. , "National study of microphthalmia, anophthalmia, and coloboma (MAC) in Scotland: Investigation of genetic aetiology," J. Med. Genet. , 2002, doi: 10.1136/jmg.39.1.16.

[4] S. P. Shah et al. , "Anophthalmos, microphthalmos, and typical Coloboma in the United Kingdom: A prospective study of incidence and risk," Investig. Ophthalmol. Vis. Sci. , 2011, doi: 10.1167/iovs.10-5263.

[5] K. A. Williamson and D. R. FitzPatrick, "The genetic architecture of microphthalmia, anophthalmia and coloboma," Eur. J. Med. Genet. , 2014, doi: 10.1016/j.ejmg.2014.05.002.

[6] T. Bardakjian, A. Weiss, and A. Schneider,Microphthalmia/Anophthalmia/Coloboma Spectrum . 1993.

[7] L. Roos, H. Jensen, K. Grønskov, R. Holst, and Z. Tümer, "Congenital Microphthalmia, Anophthalmia and Coloboma among Live Births in Denmark," Ophthalmic Epidemiol. , 2016, doi: 10.1080/09286586.2016.1213859.

[8] J. Plaisancié et al. , "Genetics of anophthalmia and microphthalmia. Part 1: Non-syndromic anophthalmia/microphthalmia," Human Genetics . 2019, doi: 10.1007/s00439-019-01977-y.

[9] A. H. Weiss, J. Longbottom, and E. A. Ross, "Complex Microphthalmos," Arch. Ophthalmol. , 1989, doi: 10.1001/archopht.1989.01070020697031.

[10] A. H. Weiss, J. Longbottom, and E. A. Ross, "Simple Microphthalmos," Arch. Ophthalmol. , 1989, doi: 10.1001/archopht.1989.01070020703032.

[11] C. J. McLean, N. K. Ragge, R. B. Jones, and J. R. O. Collin, "The management of orbital cysts associated with congenital microphthalmos and anophthalmos," Br. J. Ophthalmol., 2003, doi: 10.1136/bjo.87.7.860.

[12] E. Bermejo and M. L. Martínez-Frías, "Congenital eye malformations: Clinical-epidemiological analysis of 1,124,654 consecutive births in Spain," Am. J. Med. Genet. , 1998, doi: 10.1002/(SICI)10968628(19980217)75:5<497::AID-AJMG8>3.0.CO;2-K.

[13] M. Warburg, "Classification of microphthalmos and coloboma," J. Med. Genet. , 1993, doi: 10.1136/jmg.30.8.664.

[14] A. S. Verma and D. R. FitzPatrick, "Anophthalmia and microphthalmia," Orphanet J. Rare Dis. , 2007, doi: $10.1186 / 1750-1172-2-47$.

[15] N. S., K. D., N. Y., K. H., K. Y., and A. N., "Survey of microphthalmia in Japan," Japanese Journal of Ophthalmology . 2012.

[16] S. P. Shah et al. , "Anophthalmos, microphthalmos, and coloboma in the United Kingdom: Clinical features, results of investigations, and early management," Ophthalmology , 2012, doi: 10.1016/j.ophtha.2011.07.039. 
[17] S. E. Skalicky et al. , "Microphthalmia, anophthalmia, and coloboma and associated ocular and systemic features: Understanding the spectrum," JAMA Ophthalmol. , 2013, doi: 10.1001/jamaophthalmol.2013.5305.

[18] P. C. Carricondo, T. Andrade, L. Prasov, B. M. Ayres, and S. E. Moroi, "Nanophthalmos: A Review of the Clinical Spectrum and Genetics," Journal of Ophthalmology . 2018, doi: 10.1155/2018/2735465.

[19] N. Chassaing et al. , "Molecular findings and clinical data in a cohort of 150 patients with anophthalmia/microphthalmia," Clin. Genet. , 2014, doi: 10.1111/cge.12275.

[20] T. M. Bardakjian and A. Schneider, "The genetics of anophthalmia and microphthalmia," Current Opinion in Ophthalmology . 2011, doi: 10.1097/ICU.0b013e328349b004.

[21] M. Riera, A. Wert, I. Nieto, and E. Pomares, "Panel-based whole exome sequencing identifies novel mutations in microphthalmia and anophthalmia patients showing complex Mendelian inheritance patterns," Mol. Genet. Genomic Med., 2017, doi: 10.1002/mgg3.329.

[22] A. M. Slavotinek, "Eye development genes and known syndromes," Molecular Genetics and Metabolism . 2011, doi: 10.1016/j.ymgme.2011.09.029.

[23] I. M. MacDonald and D. Y. Mah, "Summary of heritable ocular disorders and selected systemic conditions with eye findings," Ophthalmic Genetics . 2000, doi: 10.1076/1381-6810(200003)21:1;1-i;ft029.

[24] T. Ben-Zur, E. Feige, B. Motro, and R. Wides, "The mammalian odz gene family: Homologs of a Drosophila pair-rule gene with expression implying distinct yet overlapping developmental roles," Dev. Biol. , 2000, doi: 10.1006/dbio.1999.9532.

[25] C. A. Leamey et al. , "Ten_m3 regulates eye-specific patterning in the mammalian visual pathway and is required for binocular vision," PLoS Biol. , 2007, doi: 10.1371/journal.pbio.0050241.

[26] J. Stephen et al. , "Novel truncating mutation in TENM3 in siblings with motor developmental delay, ocular coloboma, oval cornea, without microphthalmia," American Journal of Medical Genetics, Part A . 2018, doi: 10.1002/ajmg.a.40658.

[27] R. P. Tucker and R. Chiquet-Ehrismann, "Teneurins: A conserved family of transmembrane proteins involved in intercellular signaling during development," Developmental Biology . 2006, doi: 10.1016/j.ydbio.2005.11.038.

[28] M. A. Aldahmesh, J. Y. Mohammed, S. Al-Hazzaa, and F. S. Alkuraya, "Homozygous null mutation in ODZ3 causes microphthalmia in humans," Genet. Med., 2012, doi: 10.1038/gim.2012.71.

[29] B. Singh, P. Srivastava, and S. R. Phadke, "Sequence variations in TENM3 gene causing eye anomalies with intellectual disability: Expanding the phenotypic spectrum," Eur. J. Med. Genet., 2019, doi: 10.1016/j.ejmg.2018.05.004.

[30] G. Feldman, D. Kappes, J. Mookerjee-Basu, T. Freeman, A. Fertala, and J. Parvizi, "Novel mutation in Teneurin 3 found to co-segregate in all affecteds in a multi-generation family with developmental dysplasia of the hip," J. Orthop. Res., 2019, doi: 10.1002/jor.24148.

[31] F. Islam et al. , "Exome sequencing in patients with microphthalmia, anophthalmia, and coloboma (MAC) from a consanguineous population," Clin. Genet. , 2020, doi: 10.1111/cge.13830.

\section{Figure legends}

Figure 1) Family pedigree of the patient

Figure 2) Chromatogram is showing the homozygous mutation c.5069-1G>C in the TENM3 gene in the patient. 

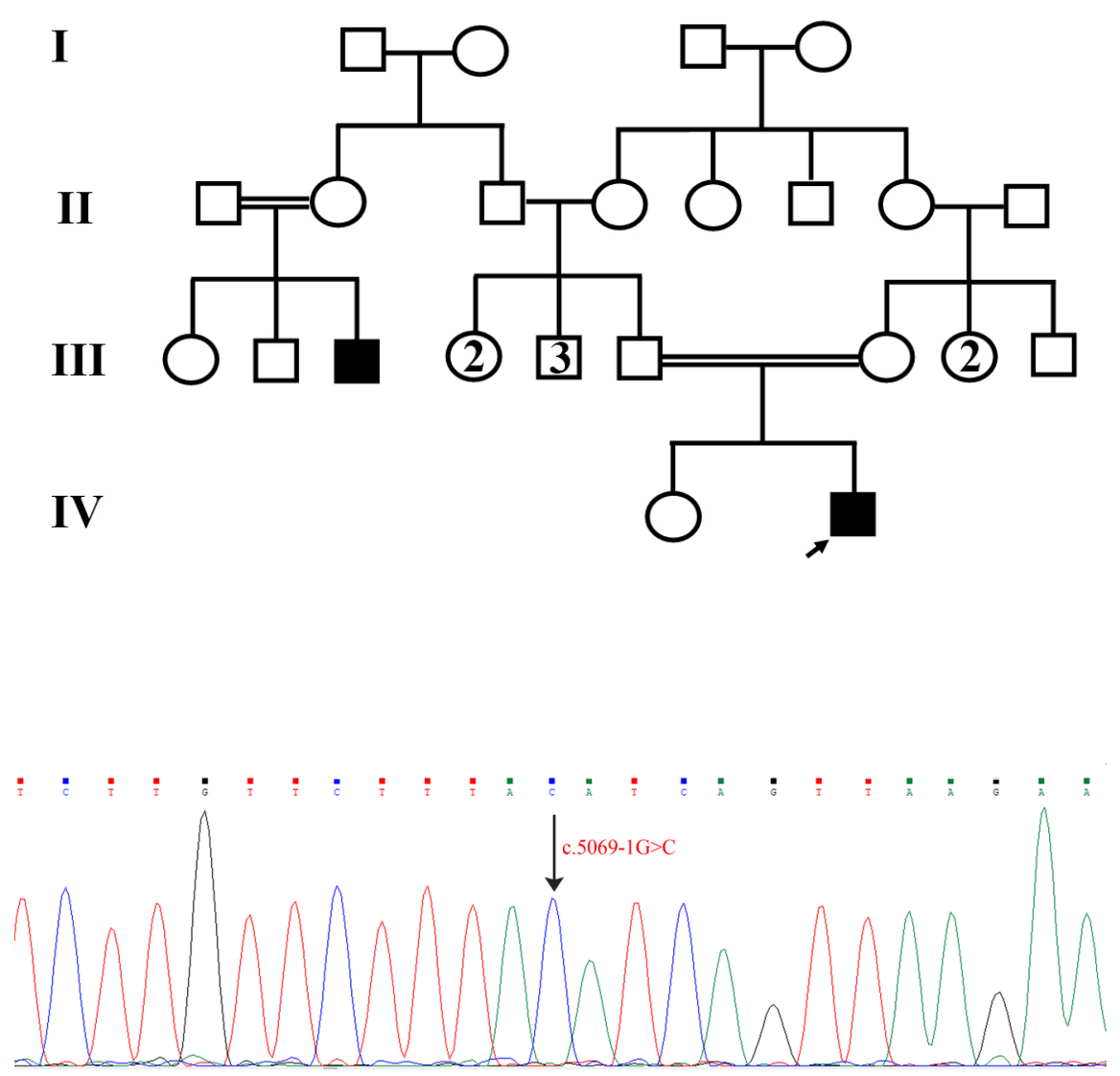